\title{
Diversity and antibacterial activityof endophytic fungi from Ceriops tagal in Muthupet mangroves
}

\author{
R.Priyadharshini, V.Ambikapathy and A. Panneerselvam \\ $P G$ and Research Department of Botany and Microbiology, A.V.V.M. Sri Pushpam College (Autonomous), \\ Poondi-613 503, Thanjavur Dist, Tamil Nadu, India
}

\begin{abstract}
Ceriops tagal mangrove is a small tree growing to 5-15m in hights with many buttresses at the base the bark is dark red. The aim of the research is to isolate and identify the fungal endophytes from the leaves of Ceriops tagal. Totally sixteen isolates of fungal endophytes were isolated from the leaf of Ceriops tagal. The antibacterial activity of Ceriops tagal against bacterial pathogen used for different solvents methanol, acetone and aqueous.
\end{abstract}

Keywords: Diversity, antibacterial activity, Muthupet mangrove, Ceriops tagal

\section{Introduction}

Mangrove forests are fascinating and complex ecosystems (Feller et al., 2010). Mangrove plants are salt-tolerant plants which act as primary producers in the estuarine food chain and they produce novel metabolites unique to the environment with various important economic and environmental functions (Bandarnayake 2002). Most mangrove plants do not consider the fact that plants in natural ecosystems have symbiotic associations with fungi. This species is widespread and found in bangaladesh, brunei Darussalam, china, Taiwan india (including nicobar and Andaman islands)

The whole of the plant is believed to be rich in an astringent principle a decoction of the bark is used to stop lemorrhages and is applied to malignant ulcers on the African coast a decoction of the shoots is used as a substitute for quinine. Malays give a decoction of the bark to women in child birth the bark is used in india as a laemostatic.

Endophytic fungi that live inside the tissues of living plants are under-explored group of microorganisms. Recently they have been received considerable attention after they were found to protect their host against insect, pests, pathogens and even domestic herbivores. Almost all the plant species harbour one or more endophytic microorganisms. Endophytes are hidden within healthy host plants are a poorly investigated group of microorganisms, but they represented an abundant and dependable source of novel bioactive compounds with huge potential for exploitation in a wide variety of medical, agricultural, and industrial areas (Tan and Zou 2001).These fungi are important to the structure, function, and health of plant communities and may be responsible for the adaptation of plants to environmental stresses (Clay and Holah 1999). In addition, mutualistic symbiosis with mycorrhizal and endophytic fungi can confer salt tolerance to plants and decrease yield losses in cultivated crops grown in saline soils (Baltruschat et al. 2008).

Endophytic fungi have been recognized as possible sources of bioactive secondary metabolites (Schulz et al., 2002, Strobel et al., 2003). There is a need to search new ecological niches for potential sources of natural bioactive agents for different pharmaceutical, agriculture, and industrial applications.

\section{Collection of plant samples}

\section{Materials And Method}

The medicinal plant of Ceriops tagal leaves were collected from the Muthupet mangroves Thiruvarur district. Healthy and mature plants were carefully chosen for sampling. The plants randomly collected and brought to the laboratory in sterile bags for further investigation.

\section{Isolation of endophytic fungi}

Asymptomatic healthy leaf materials were thoroughly washed in running tap water, then surface sterilized by a modified method of Raviraja (2005). The selected leaf segments were immersed in $95 \%$ ethanol for $30 \mathrm{sec}$, $45 \%$ sodium hypochlorite solution for $15 \mathrm{sec}$ and $95 \%$ ethanol for $30 \mathrm{sec}$ followed by rinsing with sterile distilled water three times for $10 \mathrm{sec}$ and allowed to surface dry under sterile conditions. After drying, each leaf segment was cut into approximately $0.5 \mathrm{~cm}$ squares and placed on Petri Plates containing potato dextrose agar medium (PDA). The Streptomycin sulphate $(100 \mathrm{mg} / \mathrm{L})$ was added to prevent the growth of bacteria. Then it was monitored every day for growth of endophytic fungal colonies. Fungi growing out from the samples were subsequently transferred to fresh PDA plates. 
Total number of segments analysed

\section{Identification of endophytic fungi}

The identification of fungi was done using cultural and microscopic characteristics such as shape, colour, pattern arrangement of mycelium, conidial arrangement, types of spores by using standard manuals such as, A manual of Penicillia by Kenneth (1949). The genus Aspergillus by Kenneth Raper (1965), Fungi in Agricultural Soils by Domsch and Gams (1972) and A mannuals of soil fungi by Joseph C.Gilman ( 1957). All the isolated fungi were identified up to genus level on the basis of detailed culture and microscopic study and by consulting relevant literature. The pure culture of isolated fungal strains was maintained in PDA slants at $28^{\circ} \mathrm{C}$.

\section{Lacto phenol cotton blue mounting}

A loopful culture was picked up with the help of a sterile inoculation loop and semi permanent slides were prepared using lacto phenol cotton blue. The slides were gently heated in a spirit lamp so as to release the air bubbles, if any present inside the cover glass. The excess stain was removed by using tissue paper and the cover glass was sealed with white nail polish.

\section{Antibacterial activity}

To choose were use antibacterial study four bacterial strains. Two of them were gram positive and Bacillus subtills, staphylococcus aureus another two gram negative mamely E.coli and klebsilla pneumonia. The leaf extract of ceriops tagal agar well diffusion method was used to determine the antibacterial activity. In this method wells made in the nutrient agar media using sterile cork borer and appropriate well to inoculate in individual plant extract.

\section{Result}

This resulted in association of endophytic fungi with Ceriops tagal, was selected leaves only taken for isolation of endophytic fungi. Each isolates were sub-cultured into a PDA agar plates to remove the adherent plant metabolitie from the mycelia and stored at $4^{\circ} \mathrm{C}$ for further studies.

In present investigation of sixteen endophytic fungi have been isolated leaves such as Alternaria alternate sp, Aspergillus alliaceus, A. flavus, A. granulose, A .janus, A. nidulans, A. ochraceous, A.sulphures, A. sydowi, Curvularia lunata, F. oxysporum, F. moniliforme, Phoma hedericola, Penicillium sp, $P$. janthinellum,Trichoderma viride. from the Ceriops tagal ( table 1)

\section{Antibacterial activity}

Ceriops tagal leaf extract was tested against bacterial cultures to determined and investigate their antibacterial potential with some specific solvents such as methanol, acetone and aqueous extract showed. The maximum zone of inhibition was observed in methanol $(10 \mathrm{~mm})$ extract, the minimum zone of inhibition was observed in acetone $(7 \mathrm{~mm})$, and there was no inhibition zone observe aqueous extract $(-\mathrm{mm})$ respectively the results were recorded and tabulated in table- 2

Table-1 Isolation and identification of endophytic fungi from ceriops tagal leaf sample

\begin{tabular}{|l|l|}
\hline S.NO & NAME OF THE FUNGI \\
\hline 1 & Alternaria alternata \\
\hline 2 & Aspergillus alliaceus \\
\hline 3 & A. flavus \\
\hline 4 & A. granulose \\
\hline 5 & A.janus \\
\hline 6 & A. nidulans \\
\hline 7 & A. ochraceous \\
\hline 8 & A. sulphureus \\
\hline 9 & A. sydowi \\
\hline 10 & Curvularia lunata \\
\hline 11 & Fusarium oxysporum \\
\hline 12 & F. moniliforme \\
\hline 13 & Phoma hedericola \\
\hline 14 & Penicillium sp \\
\hline 15 & P. janthinellum \\
\hline 16 & Trichoderma viride \\
\hline
\end{tabular}


Table-2 Studies on the effect of antibacterial activities of ceriops tagal plant leaf extract against some bacterial pathogen

\begin{tabular}{|l|l|l|l|c|}
\hline \multirow{2}{*}{ S.NO } & \multirow{2}{*}{ Bacterial pathogens } & \multicolumn{3}{|l|}{ Zone of inhibition (in mm) } \\
\cline { 3 - 5 } & & methanol & acetone & aquoeus \\
\hline $\mathbf{1}$ & Bacillus subtilis & $2 \mathrm{~mm}$ & $3 \mathrm{~mm}$ & - \\
\hline $\mathbf{2}$ & Staphylococcus aureus & $4 \mathrm{~mm}$ & $2 \mathrm{~mm}$ & - \\
\hline $\mathbf{3}$ & E. coli & $4 \mathrm{~mm}$ & - & - \\
\hline $\mathbf{4}$ & klebsilla & - & $2 \mathrm{~mm}$ & - \\
\hline
\end{tabular}

\section{Discussion}

The endophytic fungi are one of the most unexplored and diverse group of organisms that make symbiotic associations with higher life forms and may produce beneficial substance for host (Weber, 1981 and Shiomi et al., 2006). Endophytic organisms have received considerable attention after they were found to protect their host against insect pests, pathogens and even domestic herbivorous (Weber, 1981). Fungi have been widely investigated as a source of bioactive compounds an excellent responsibility for anticancer drug taxol, which had been previously to occur only in the plants (Strobel and Daisy, 2003).

In the present investigation sixteen endophytic fungi were isolated from the leaves of ceriops tagal. The endophytic fungi such as Alternaria alternate sp, Aspergillus alliaceus, A. flavus, A. granulose, A .janus, A. nidulans, A. ochraceous, A.sulphures, A. sydowi, Curvularia lunata, F. oxysporum, F. moniliforme, Phoma hedericola, Penicillium sp, P. janthinellum, Trichoderma viride.

The water extracts of A. nilotica, J. zeylanica, L. camera and S. asoca, were found to be the most active against bacteria as well as fungal pathogens. The wells containing a concentration of 9.375-150.0 $\mu \mathrm{g} / \mathrm{ml}$ extracts of water and methanol inhibited the visible growth of all the bacterial species (Table 2). Methanol extracts of A. nilotica and J. zeylanica exhibited good activity in the range of 18.75-75.0 $\mu \mathrm{g} / \mathrm{ml}$. The chloroform and acetone fractions were found to be less active. The MICs of water and methanol fractions against all the fungi were observed to be in a range of 75.0-300.0 $\mu \mathrm{g} / \mathrm{ml}$. However, A. nilotica was observed to be inactive against fungal Dabur et. al., Afr. J. Trad. CAM (2007) 4 (3): 313 - 318318 pathogens. Water soluble fraction of the flowers and bud of S. asoca were reported to have significant inhibitory effect against Sh. boydis (Narang et al, 1962) and the $50 \%$ ethanolic extract of the whole plant was reported to be inactive. The study, methanolic extract of stem bark of S. asoca exhibited significant inhibitory activity against bacteria used. In the present study of methanol leaf extract from the plant ceriops tagal showed antibacterial activity against all the tested microorganisms.

\section{Conclusion}

In the present study totally sixteen endophytic fungi were isolated from ceriops tagal in Muthupet mangroves. Focusing on the invistication of endophytic fungal diversity. We have described the antibacterial properties of the methanol against the tested microbes. Based on our findings we envision that the

\section{Acknowledgement}

The authors are very much thankful to the Secretary and Correspondent and Principal of A. Veeriya Vandayar Memorial Sri Pushpam College (Auto.), Poondi, Thanjavur (Dist) Tamil Nadu for providing lab orangesed facilities to do this work.

\section{References}

[1]. Baltruschat, H., J. Fodor, B.D. Harrach, E. Niemczyk, B. Barna, G. Gullner, A. Janeczko, K. Kogel, P. Schafer, I. Schwarczinger, A. Zuccaro and A. Skoczowski. (2008). Salt tolerance of barley induced by the root endophyte Piriformospoindica is associated with a strong increase in antioxidants. New Phytol. 180: 501-510.

[2]. Bandarnayake, W.M., (2002). Bioactivities, bioactive compounds and chemical constituents of mangrove plants. Wetlands Ecol. Manage. 10: 421-452.

[3]. Clay, K and J. Holah. (1999). Fungal endophyte symbiosis and plant diversity in successional fields. Science 285: $1742-1744$.

[4]. Domsch K.H and Gams, (1972). Fungi in Agricultural soils. Halsted Press Division, Johnwiley and sons Inc. NewYork.

[5]. Feller, I.C.; Lovelock, C.E.; Berger, U.; McKee, K.L.; Joye, S.B and Ball, M.C. (2010). Biocomplexity in mangrove ecosystems. Annu. Rev. Mar. Sci, 2, 395-417.

[6]. Joseph C.Gilman (1957). The Iowa state College press-Ames, Iowa, USA

[7]. Kenneth B. Raper, Charles Thom and Dorothy I.Fennel (1949). "A manual of the Penicillia," Ohio State University, Baltimore, MD., USA.The Williams \&Williams company.

[8]. Kenneth B. Raper, Dorothy I.Fennel and Peter K.C.Austwich. (1965). The genus Aspergillus, Sans Tache, the Williums \& Williums Company, Baltimore.

[9]. Strobel G and Daisy B (2003), Bioprospecting for microbial endophytes and their natural products, Microbiology and Molecular Biology Review, 67: 491-502.

[10]. Tan, R.X and Zou. W.X. (2001). Endophytes: a rich source of functional metabolites. Nat. Prod. Rep. 18: 448-459.

[11]. Schulz B, Boyle C, Draeger S, R"ommert A-K \& Krohn K (2002) Endophytic fungi: a source of novel biologically active

[12]. Narang, G. D., Nayar, S., Mcndiratta, D. K . (1962). Antibacterial activity of some indigenous drugs, J. Vet. Animal husb. Res. 6(1): $22-25$. 